\title{
Attitudes toward Breastfeeding and Breastfeeding Practice: Lack of Support for Breastfeeding in Public as a Factor in Low Breastfeeding Rates
}

\author{
1 Željka Buturović \\ 1 Suzana Ignjatović \\ 1 Mirjana Rašević \\ 1 Institute of Social Sciences Belgrade
}

\section{Summary}

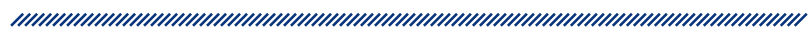

Serbia is a country with one of the lowest breastfeeding rates in the world: $51 \%$ of women initiate breastfeeding and only $13 \%$ exclusively breastfeed for 6 months. Since Serbian social and health policies are rather favourable, the focus should be placed on psychosocial and cultural factors and attitudes as factors in breastfeeding decisions. Public breastfeeding is one of the most controversial issues. Lack of support for public breastfeeding could, by discouraging women from breastfeeding more openly, significantly contribute to low rates of breastfeeding and its short duration.

The aim of this study was to determine to what extent mothers, fathers, and non-parents were supportive of public breastfeeding, independently and compared to their other attitudes about breastfeeding. A survey of 1884 Serbian adults - mostly highly engaged mothers was conducted online. The average support for uncovered breastfeeding in public was 6.3 on a 10-point scale. There was a statistically significant variation in support for public breastfeeding by breastfeeding intensity (among mothers), parenting status and gender. There were no significant differences in support by age and education. Support for public breastfeeding was lower than support for breastfeeding in general. Even highly engaged and informed mothers, who are very supportive of breastfeeding in general, are not very supportive of public breastfeeding. The same tendency was found in the general public represented by non-parents in our sample. A widespread disapproval of public breastfeeding could present practical obstacles to breastfeeding. These findings indicate that attitudes toward breastfeeding should be taken into account in future policies aimed at supporting breastfeeding.

Keywords: infant feeding, breastfeeding in public, breastfeeding obstacles, attitudes toward breastfeeding

Article received: 09.07.2017.

Article accepted: 15.10.2017.

DOI: $10.24141 / 1 / 3 / 2 / 1$

Author for correspondence:

Suzana Ignjatović

Institute of Social Sciences, Kraljice Natalije 45,

11000 Belgrade, Serbia

Email:signjatovic@idn.org.rs

Phone: +381 643299442 


\section{Introduction}

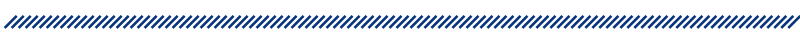

While welfare/family policies and public health initiatives remain an important consideration in breastfeeding success ${ }^{1}$, recent studies have also shown a link between breastfeeding attitudes and infant feeding choices ${ }^{2}$, perceived breastfeeding efficacy ${ }^{3}$ and duration of breastfeeding ${ }^{4}$, thus shifting the focus from socio-demographic, institutional and biomedical factors to psychological and psychosocial factors and attitudes. ${ }^{4,5}$ The most recent WHO position paper stating that promotion of breastmilk substitutes and complementary foods undermines breastfeeding (including "growing-up milks" advertised for older children) is likewise consistent with the view that breastfeeding attitudes play a significant role in the decision to breastfeed and the duration of breastfeeding. ${ }^{6}$

In line with this, attitudes toward breastfeeding in public have been given an increased importance as a research subject. ${ }^{4,7,8}$ Experiencing discomfort can be one of the reasons for avoiding breastfeeding in public, especially when adequate facilities are not available, ultimately leading to breastfeeding cessation. Difficulties related to breastfeeding in public affect all women, regardless of socio-economic and class aspects. ${ }^{7}$

Though overall attitudes toward breastfeeding are generally positive (for example, the United States) ${ }^{9}$, negative attitudes toward public breastfeeding appear to be common. In their study of Australian GP registrars, Brodribb and colleagues ${ }^{10}$ found the mean score for the attitude "Women should not breastfeed in public places, on a 1-5 scale" to be $M=4.3$. According to Scott and colleagues, ${ }^{2}$ $28 \%$ of fathers of breastfed infants in Scotland agreed that women "should not breastfeed in public places such as restaurants". Another survey from Western Australia showed a decreasing trend in negative attitudes toward breastfeeding in different public spaces (shopping centres, restaurants, workplace) over years (1995-2009); however, there is still a small but substantial proportion of those who opt for "It depends (on how obvious it is)". ${ }_{11}$ Over half of respondents from New York City were unsupportive of public breastfeeding (50.4\%), but significant differences were identified by education, age, and race. ${ }^{12}$

Serbia has one of the lowest breastfeeding rates in the world: only $13 \%$ of mothers exclusively breastfeed for 6 months $^{13}$, despite relatively favourable institutional conditions. Employed mothers are entitled to one year of full-rate equivalent paid maternity leave for their first and second child, and two years for their third and each subsequent child. ${ }^{14}$ Women's health services are provided in public primary health centres and by gynaecologists. Acceptable rates of over $95 \%$ of antenatal care and assistance during delivery by skilled personnel have been achieved; $94 \%$ of women were visited by a community nurse during the week after the delivery and the average number of postnatal visits by a community nurse after birth is $4.3 .{ }^{13}$ However, a recent survey has shown some issues in maternity care, especially when it comes to inadequate breastfeeding initiation at hospitals, including "baby-friendly" wards..$^{15}$

On the other hand, attitudes toward breastfeeding in public are more problematic. Images of public breastfeeding in the media and public spaces are rare. A recent anthropological study of breastfeeding mothers in Serbia shows that mothers are receiving mixed messages with respect to breastfeeding, including comments such as "breastfeeding is unhealthy and primitive" by their partners and others. ${ }^{16}$

Since these issues have not been systematically investigated so far, here we explore the possibility that a lack of support for breastfeeding in public plays a role in Serbian low breastfeeding rates. We focused on respondents' opinion about uncovered breastfeeding in public, both as a proxy of mother's readiness to breastfeed in public as a part of her daily routine and as the most critical part of the general public's readiness to accept breastfeeding in public spaces.

\section{Methods}

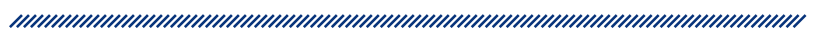

\section{Design and sample}

This study is a part of a larger project that aims to understand Serbian parents' attitudes and adjustments during the first year of a baby's life. As a part of this larger project, a 74-item questionnaire, which included socio-demographic questions as well as items addressing personal experiences with parenthood and breastfeeding, and life satisfaction, was created. The Institutional Review Board of the Institute of Social Sciences approved the purpose and procedures of the study.

The questionnaire was posted online using Google Forms. Various popular parenting newspapers and blogs agreed 
to add the survey link to their websites for a limited period. The data collection commenced on January $19^{\text {th }}$, 2015 and ended on April $18^{\text {th }}, 2015$. The respondents were informed about the purpose of the study on the first page of the online questionnaire. Analyses were conducted using SPSS on a cleaned-up sample of 1884 respondents (mothers, fathers, and non-parents) who answered all relevant demographic and breastfeeding questions.

\section{Measurement}

In this study, a subset of items from the larger questionnaire was utilized, including demographic questions, an item about breastfeeding in public and items about breastfeeding knowledge and attitudes. The latter examined to what extent respondents agreed with a list of statements, measured by eleven 10-point Likert-type items. These statements covered different domains: health and psychological benefits for the baby ("Breastfeeding is necessary for bonding between the mother and child", Breastfeeding is necessary for the development of the baby's immune system", "A breastfed child is healthier", "A breastfed child is more intelligent, and this improves its life prospects"); breastfeeding benefits for the mother ("Breastfeeding reduces the risk of breast cancer", "Breastfeeding benefits the mother's weight regulation after giving birth"), moral and other norms related to breastfeeding ("The mother's diet is very important for the baby's health"; "The mother's duty is to try hard to succeed in breastfeeding") and economic benefits of breastfeeding ("Breastfeeding is the most cost-effective option for the family"; "Breastfeeding is the most practical and simple way of infant feeding"). The question about breastfeeding in public was phrased in a somewhat extreme modality, explicitly asking about the most problematic aspect of breastfeeding in public - an uncovered breast: "A woman should be allowed to breastfeed in public freely without covering her breast".

\section{Data analysis}

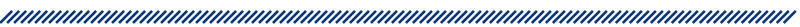

Data analysis consisted of two parts. In the first part, we compared attitudes toward public breastfeeding among mothers, fathers and non-parents. In the second part, we looked at possible relationships between breastfeeding attitudes and the duration of breastfeeding among mothers. Differences in the outcome variable among three groups of respondents by demographic variables were tested using analysis of variance and t-tests. In addition, the average score was calculated out of ten questions related to positive breastfeeding attitudes, and this new variable was used in a logistic analysis as one of the predictors of the mother's support for public breastfeeding.

\section{Results}

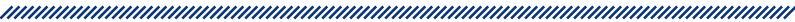

Majority of the sample were women (95\%) and $94 \%$ were parents. The average age was 34.6 years ( $\mathrm{SE}=.14$ ). $22 \%$ of the sample had a high school education or less, $13 \%$ had some college education, 39\% were still in college, and $25 \%$ had a college degree. The crux of our results is presented in Table 1. The distribution of support for public breastfeeding on a scale from 1 to 10 was trimodal, clustering around values 1,5 , and $10.31 \%$ of respondents chose values less than five (including 19\% of those who chose the lowest value 1), 12\% chose the value 5 and $30 \%$ chose the value 10 . Analyses of variance showed that variation in support for breastfeeding by education ( $F=1.15$, $p>0.05)$ and age $(r=0.01, p>0.05)$ were not significant. However, there were statistically significant differences between parents and non-parents $(t=3.99, p<0.01)$ and between men and women ( $t=2.04, p<0.05)$.

Table 1. Support for breastfeeding in public by gender, education and parenting status

Women who breastfeed in public should do it freely, without covering their breasts

\begin{tabular}{|c|c|c|}
\hline Variable & $n$ & Mean \\
\hline Total & 1884 & $6.25(6.10-6.41)$ \\
\hline Sex & & \\
\hline Male & 104 & $6.82(6.26-7.38)$ \\
\hline Female & 1780 & $6.22(6.06-6.38)$ \\
\hline Education & & \\
\hline High school or less & 419 & $6.12(5.79-6.46)$ \\
\hline Some college & 248 & $5.97(5.54-6.41)$ \\
\hline College graduate & 740 & $6.33(6.09-6.58)$ \\
\hline Graduate degree & 477 & $6.39(6.09-6.69)$ \\
\hline Parenting status & & \\
\hline Mother & 1683 & $6.30(6.13-6.46)$ \\
\hline Father & 88 & $6.90(6.28-7.15)$ \\
\hline Non-parent & 113 & $5.02(4.41-5.63)$ \\
\hline
\end{tabular}

Note. Numbers in parentheses denote $95 \%$ confidence intervals. 


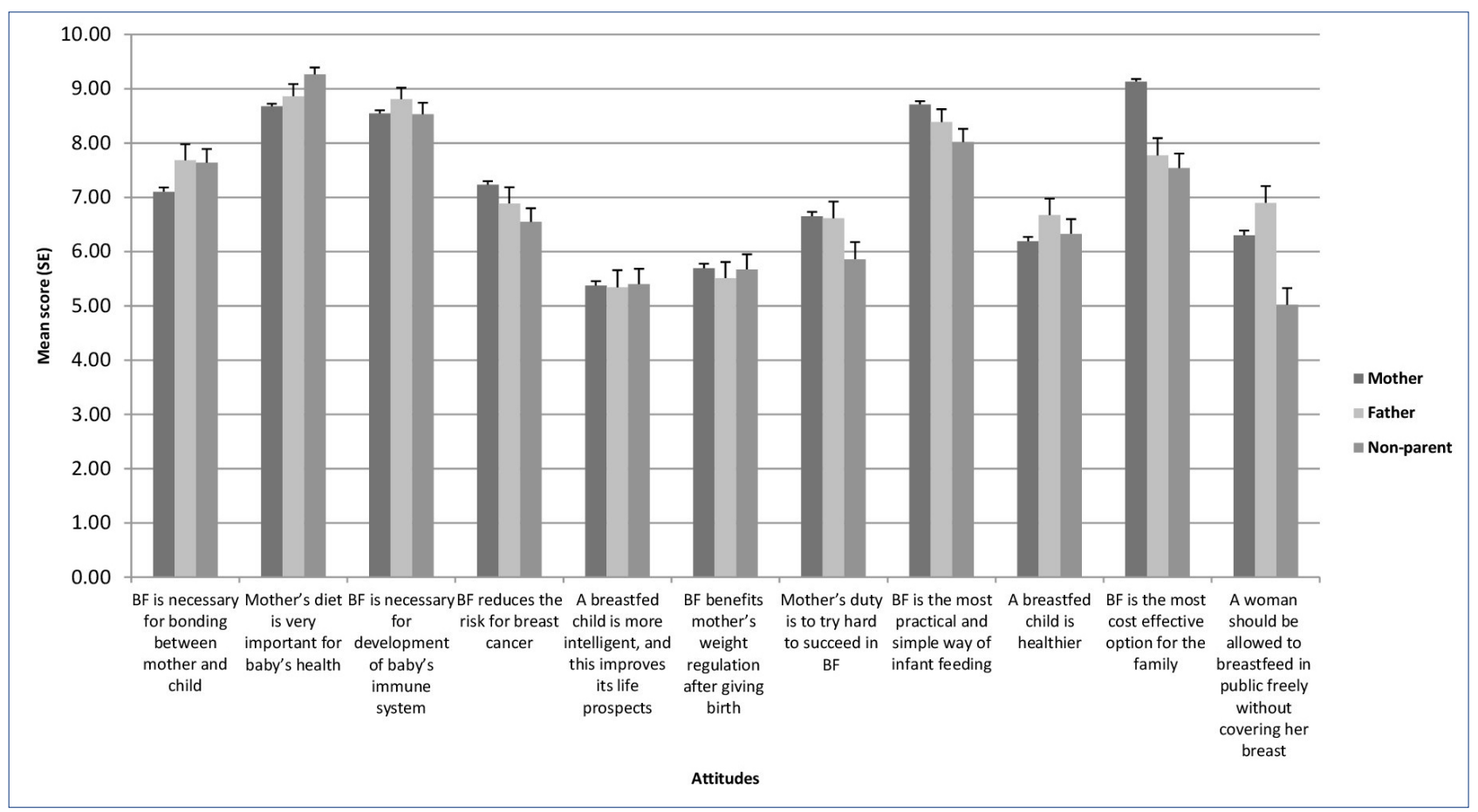

Figure 1. Attitudes toward breastfeeding and breastfeeding in public broken down by parenting status. Whiskers indicate standard error of the mean for each score.

Overall lukewarm support for public breastfeeding is somewhat contrary to some of the attitudes of our sample toward breastfeeding (Figure 1). Since Cronbach's alpha for these 10 items was .87 , we calculated their average as a measure of positive breastfeeding attitudes. The mean ten-item positive breastfeeding attitudes score was $6.96(95 \% \mathrm{Cl}=(6.88,7.12))$. The Pearson correlation between ten-item positive breastfeeding attitudes score and attitudes toward public breastfeeding was $r=.19(p<0.01)$.

In the second part of the analysis, we looked at associations between mothers' duration of breastfeeding and their attitudes toward public breastfeeding (Table 2). 1643 mothers have rated their breastfeeding intensity on a scale from 1 to 10: the mean was 7.65 ( $\mathrm{SE}=0.07$ ). Breastfeeding duration was significantly related to attitudes toward public breastfeeding $(F=13.18, p<0.05)$ : support for uncovered public breastfeeding was the highest among mothers who exclusively breastfed for six months or more and lowest among those who did not try breastfeeding. However, even among these most intensively breastfeeding mothers, 23\% chose a level lower than 5 for uncovered public breastfeeding and $13 \%$ chose level 1 . The Pearson correlation between self-reported breastfeeding intensity and attitudes toward public breastfeeding was $r=.14(p<0.05)$.

\begin{tabular}{|c|c|c|}
\hline $\begin{array}{c}\text { Table 2. Support for breastfeeding in public } \\
\text { among mothers by duration of breastfeeding }\end{array}$ \\
\hline $\begin{array}{c}\text { Women who breastfeed in public should do it } \\
\text { freely, without covering their breasts }\end{array}$ \\
\hline Variable & $n$ & Mean \\
\hline Total & 1884 & $6.25(6.10-6.41)$ \\
\hline $\begin{array}{c}\text { Breastfeeding duration } \\
\text { (mothers only) }\end{array}$ & 1652 & \\
\hline $\begin{array}{c}\text { Short time non-exclusive } \\
<6 \text { months, exclusive }\end{array}$ & 296 & $5.68(5.27-6.09)$ \\
\hline $6+$ months, exclusive & 821 & $4.91(4.16-5.66)$ \\
\hline $\begin{array}{c}6+\text { months non-exclusive } \\
\text { Haven't tried }\end{array}$ & 304 & $5.94(6.71-7.16)$ \\
\hline $\begin{array}{c}\text { Attempted to breastfeed, but } \\
\text { it did not work out }\end{array}$ & $17.59-6.34)$ \\
\hline Note. Numbers in parentheses denote $95 \%$ confidence intervals. \\
\hline
\end{tabular}

A dichotomized public breastfeeding support variable, where mothers who chose 7 or lower on 1-10 group were assigned to one group and the rest to the other, was created and used as an outcome variable for a logistic regression with predictors of positive breastfeeding attitudes and breastfeeding duration. Compared 
to mothers who breastfed exclusively for six months or longer, mothers who breastfed non-exclusively for six months or more were significantly less likely (AOR = $.60 ; 95 \% \mathrm{Cl}, 0.46-0.78$ ) to be supportive of public breastfeeding, and so were those who breastfed exclusively for less than six months (AOR $=0.40 ; 95 \% \mathrm{Cl}, 0.25-0.65$ ). There was also an increase in odds of supporting public breastfeeding ( $A O R=1.22 ; 95 \% \mathrm{Cl}, 1.14-1.30)$ for each one-point increase in positive breastfeeding attitudes.

\section{Discussion}

Our study suggests that a significant portion of highly engaged Serbian parents is strongly opposed to public breastfeeding: almost a fifth of our sample chose the strongest disapproval level of '1' on a 1-10 scale. Furthermore, while breastfeeding rates in Serbia are among the lowest in the world, mothers in our sample breastfed at very high rates. Despite that, their support for public breastfeeding was lukewarm. Even among mothers who breastfed most intensively - those who breastfed exclusively for 6 months or more $-23 \%$ disapproved and $13 \%$ very strongly disapproved of uncovered public breastfeeding.

Since our sample contained a highly disproportionate number of breastfeeding mothers, it therefore very likely contained a disproportional number of respondents who were highly supportive of public breastfeeding. Consequently, it is highly unlikely that support for public breastfeeding in Serbia is anything but significantly lower than the already middling value we observed in our study. Clearly, further studies using representative samples and a wider range of outcome variables are needed. In contrast to other similar studies (for example, Mulready-Ward and Hackett ${ }^{12}$ ), we found no variation across age and education, suggesting that these attitudes are widely shared.

The lukewarm support for public breastfeeding is unlikely to be due to generalized uneasiness with nudity among Serbs. On the contrary, Serbian attitudes toward nudity are rather relaxed: a vast majority of women of all ages wear bikinis, topless women at beaches do not draw attention and female children often do not wear swim tops till elementary school. A recent media analysis has shown a high level of tolerance in the media for sex-related content and nudity. ${ }^{17}$ It appears that it is nude nursing breasts rather than nude breasts per se that are the issue. This is consistent with the findings from Morris et al, which revealed nudity (sexualisation of the breast) to be just one of the factors in opposition to breastfeeding (aversion to bodily fluids and embarrassment of being caught looking are also relevant factors), others relating loosely to a 'change of rules' (compared to the past, other countries, manners etc.). ${ }^{18}$

Although media images of pregnant and post-natal bodies are very common in Serbia, those of breastfeeding are not. Mass public breastfeeding events have not been well received by the general public. ${ }^{19}$ Recently, "breastfeeding benches" were installed in three Belgrade public parks, which can increase exposure to public breastfeeding. ${ }^{20}$ This is important because it has been shown that even posters showing breastfeeding mothers can gradually lower discomfort in observers, and thus lead to better acceptance of breastfeeding in public. ${ }^{21}$ Acker at al. showed that, even when people are aware of the benefits of breastfeeding, they are not comfortable with breastfeeding because it draws attention to highly sexualized parts of women's bodies, and it presents a violation of gender role stereotypes about female modesty. ${ }^{22}$

The normalization of breastfeeding in public by presenting human milk as food instead of perception of milk as a bodily fluid ${ }^{18}$ and exposure to breastfeeding ${ }^{22}$ have been emphasized in recent studies. Acker et al. ${ }^{22}$ found that parental exposure to breastfeeding makes them more comfortable with breastfeeding in public, and we have also found parents to be more accepting of public breastfeeding than non-parents. Consistent with that, Shafer et al. showed that personal breastfeeding experience of the mother's support network (including her mother, partner, and health care provider) significantly influenced the type of advice on pursuing breastfeeding given to new mothers. ${ }^{23}$ Taken together, this speaks to the possibility that lack of familiarity with breastfeeding reinforces negative attitudes toward it and especially toward the sensitive issue of breastfeeding in public. The relationship between breastfeeding visibility, attitudes and practice in Serbia requires further examination.

\section{Conclusion}

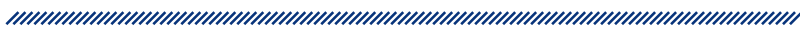

Our exploratory findings of Serbians' attitudes toward breastfeeding in public are consistent with the view that broader breastfeeding culture, in addition to so- 
cio-demographic and institutional factors, plays a role in breastfeeding rates. As a link between familiarity and practice, acceptance of public breastfeeding could play an important part in fostering a more supportive breastfeeding culture.

\section{Funding Acknowledgement}

This research was supported by the Ministry of Education, Science and Technological Development of the Republic of Serbia (project grants: III 47010 and III 47006).

\section{References}

1. Lubold AM. The effect of family policies and public health initiatives on breastfeeding initiation among 18 high-income countries: a qualitative comparative analysis research design. Int Breastfeed J. 2017;12(34):1-11.

2. Scott JA, Shaker I, Reid M. Parental Attitudes Toward Breastfeeding: Their Association with Feeding Outcome at Hospital Discharge. Birth. 2004;31(2):125-131.

3. Schafer EJ, Campo S, Colaizy TT, Mulder PJ, Breheny P, Ashida S. First-time mothers' breast-feeding maintenance: role of experiences and changes in maternal perceptions. Public Health Nutr. 2017;7:1-10.

4. Buturović Ž, Ignjatović S, Rašević M. Challenges of Early Motherhood: Breastfeeding Difficulties and Life Satisfaction. Stanovništvo. 2016;54(1):1-14.

5. Scott JA, Diet GD, Kwok YY, Synnott K, Bogue J, Amarri S, et al. Comparison of Maternal Attitudes to Breastfeeding in Public and the Association with Breastfeeding Duration in Four European Countries: Results of a Cohort Study. Birth. 2015;42(1):78-85.

6. Grummer-Strawn LM, Zehner E, Stahlhofer M, Lutter C, Clark D, Sterken E, et al., on behalf of the WHO/UNICEF NetCode. New World Health Organization guidance helps protect breastfeeding as a human right. Matern Child Nutr. 2017;13(4):e12491.

7. Boyer K. Affect, corporeality and the limits of belonging: Breastfeeding in public in the contemporary UK. Health Place. 2012;18(3):552-560.

8. Newell L. Disentangling the politics of breastfeeding. Child Geogr. 2013;11(2):256-261.

9. Nelson JM, Li R, Perrine CG, Scanlon KS. Public Opinions About Infant Feeding in the United States. Birth. 2016;43(4):313-319. doi: https://doi.org/10.1111/birt.12248
10. Brodribb W, Fallon A, Jackson C, Hegney D. Breastfeeding and Australian GP registrars-their knowledge and attitudes. J Hum Lact. 2008;24(4):422-430.

11. Meng X, Daly A, Pollard CM, Binns CW. Community Attitudes toward Breastfeeding in Public Places among Western Australia Adults, 1995-2009. J Hum Lact. 2013;29(2):183-189.

12. Mulready-Ward C, Hackett M. Perception and attitudes: breastfeeding in public in New York City. J Hum Lact. 2014;30(2):195-200.

13. Statistical Office of the Republic of Serbia and UNICEF. Serbia Multiple Indicator Cluster Survey 2014; Serbia Roma Settlements - Multiple Indicator Cluster Survey 2014. Belgrade: Statistical Office of the Republic of Serbia and UNICEF; 2014.

14. Zakon o radu. Službeni glasnik Republike Srbije. 24/2005, 61/2005, 54/2009, 32/2013, 75/2014.

15. Arsenijevic J, Pavlova M, Groot W. Shortcomings of Maternity Care in Serbia. Birth. 2014;41(1):14-25.

16. Srdić-Srebro A. Materinstvo: prirodni zakon ili sociokulturni konstrukt? Etnološko-antropološke sveske. 2014;23:37-50.

17. UNICEF. Označavanje TV sadržaja i zaštita dece - analiza programa nacionalnih emitera. Beograd: UNICEF; 2013.

18. Morris C, Zaraté de la Fuente GA, Williams CE, Hirst C. UK Views toward Breastfeeding in Public: An Analysis of the Public's Response to the Claridge's Incident. J Hum Lact. 2016;32(3):472-480.

19. Krstić Lj. Dojenje na javnom mestu nije sramota! Beogradske mame doje decu na Adi. Blic [Internet]. 2014 [pristupljeno 31.01.2017.]. Dostupno na: http://zena. blic.rs/Bebe/23248/Dojenje-na-javnom-mestu-nije-sramota-Beogradske-mame-doje-decu-na-Adi

20. Klupa za dojenje u Zemunu. Studio B [Internet]. 2016 [pristupljeno 31.01.2017.]. Dostupno na: http://studiob. rs/klupe-za-dojenje

21. Vieth A, Woodrow J, Murphy-Goodridge J, O'Neil C, Roebothan B. The Ability of Posters to Enhance the Comfort Level with Breastfeeding in a Public Venue in Rural Newfoundland and Labrador. J Hum Lact. 2016;32(1):174-181.

22. Acker M. Breast is Best...But Not Everywhere: Ambivalent Sexism and Attitudes Toward Private and Public Breastfeeding. Sex Roles. 2009;61(7-8):476-490. doi: https://doi.org/10.1007/s11199-009-9655-z

23. Schafer EJ, Williams NA, Digney S, Hare ME, Ashida S. Social Contexts of Infant Feeding and Infant Feeding Decisions. J Hum Lact. 2016;32(1):132-140. 


\section{STAVOVI PREMA DOJENJU I PRAKSA DOJENJA: NEDOSTATAK PODRŠKE DOJENJU U JAVNOSTI KAO ČIMBENIK NISKIH STOPA DOJENJA}

1 Željka Buturović

1 Suzana Ignjatović

1 Mirjana Rašević

1 Institut društvenih nauka Beograd

\section{Sažetak}

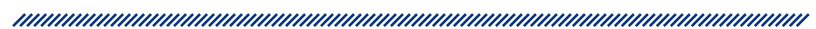

Srbija je zemlja s jednom od najnižih stopa dojenja u svijetu: 51 \% žena započne s dojenjem, a samo $13 \%$ isključivo doji šest mjeseci. S obzirom na to da su srpske društvene i zdravstvene politike poprilično pogodne, potrebno je usredotočiti se na psihosocijalne i kulturne čimbenike te stavove kao čimbenike u donošenju odluke o dojenju. Dojenje u javnosti jedno je od najkontroverznijih pitanja. Nedostatak podrške dojenju u javnosti mogao bi biti važan uzrok niskih stopa dojenja i njegova kratkog trajanja zbog obeshrabrivanja žena da slobodnije doje.

Cilj je ovog istraživanja utvrditi u kojoj mjeri majke, očevi i osobe koje nisu roditelji podržavaju dojenje u javnosti, samostalno i u usporedbi s njihovim drugim stavovima o dojenju. Istraživanje koje je obuhvaćalo 1884 odraslih Srba, većinom vrlo angažiranih majki, provedeno je putem interneta. Prosječna podrška za nepokriveno dojenje u javnosti iznosila je 6,3 na skali od 1 do 10. Postoji statistički značajna razlika u podršci dojenju u javnosti prema intenzitetu dojenja (među majkama), roditeljskom statusu i spolu. Nema značajne razlike u podršci prema dobi i obrazovanju. Podrška dojenju u javnosti niža je od podrške dojenju općenito. Čak i vrlo angažirane i informirane majke, koje u velikoj mjeri podupiru dojenje općenito, ne podržavaju dojenje u javnosti. Ista tendencija otkrivena je u široj javnosti koju u našem uzorku predstavljaju osobe koje nisu roditelji. Opće neodobravanje dojenja u javnosti moglo bi biti praktična prepreka dojenju. Ovi rezultati ukazuju na to da je stavove o dojenju potrebno uzeti u obzir u budućim politikama za podršku dojenju.

Ključne riječi: hranjenje d,ojenčeta, dojenje u javnosti, prepreke dojenju, stavovi o dojenju 